\title{
Innovative Human Resource Management Model in Vocational High School
}

\author{
Ali Hamdani \\ Post Graduate Program of Universitas Negeri Medan \\ Medan, Indonesia \\ alihamdani3878@gmail.com
}

\author{
H. Syaiful Sagala \\ Post Graduate Program of Universitas Negeri Medan \\ Medan, Indonesia \\ syaiful_sagala@yahoo.co.id
}

\begin{abstract}
Innovative human resource management models in schools are used to manage the human resources of educators and education personnel in order to have quality. The main advantage of this model lies in the phase that directs educators on improving competencies that can produce competent graduate. The purpose of this study was to determine the innovative management model of Human Resources Educators and educational staff in Vocational High School (SMK). This research was qualitative research by investigate information from the Human Resource Management (HRM) team and the managed parties. Data obtained through observation techniques, interviews and documentation. The validity of data was through confirmability, dependability, credibility, and triangulation. The results of this study form of consists of: the determination of human resource quality planning was based on the quality policy and quality goals human resource that refer to the vision and mission; procurement of human resources implemented to fulfill the requirements of educators and education personnel through the activities recruitments; human resource development was carried out to improve the competence of educators and education personnel through formal education enhancement, tracks of external and internal training; evaluation of human resources implemented to improve the performance of educators and educational staff through monitoring activities, assessment, performance evaluation, and supervision. The conclusion was the human resource management had been implemented specifically and effectively in SMK Negeri 2 Depok Sleman had met the required human resource management standards.
\end{abstract}

Keywords: Human Resource Management; Quality Planning; Procurement; Development; Evaluation.

\section{INTRODUCTION}

Management of human resources of a school organization is one of the determinants of the success of schools to achieve its objectives. Lately the attention of many school organizations to conduct studies and give serious attention to the management of human resources. Private and public education institutions, need teachers and employees who have good quality human resources, meaningless systems and advanced technology without accompanied by competent human resources in their field.

In the 1990s the LBA Consulting Group conducted an important research on the factors that most contributed to the creation and maintenance of organizational excellence. This research has been conducted for over 25 years by observing various successful and lasting organizations, as well as organizations that failed and then died. Lance Berger and Dorothy R. Berger [1] concluded from the results of the study that there are six human resource condition that must be fulfilled, that is: "(1) Performance-oriented culture; (2) low turnover rate of employees (especially in groups of employees with excellent performance / very special); (3) a relatively high level of employee satisfaction; (4) qualified human resource cadre; (5) effective investment in the form of remuneration and human resource development; and (6) employee selection process and competency based performance evaluation (as a success factor)".

A superior organization, usually supported by proactive and systematic HR management, especially in the process of achieving the above conditions. Organizations that fail and then die usually take care of human resources at random.

In related with mentioned above subsequently in a school organization needs to have a special manager in the field of human resources educators and educational staff, if the human resources of educators and education personnel were well managed, in thus the organization will have expert and competent human resources in their field, in order that the purpose of the establishment of the organization will be achieved in accordance with the vision and mission of the organization. To manage human resources, clear guidelines were required, they should be written in writing in a jointly defined organization.

SMK Negeri 2 Depok Sleman is an educational institution that has the obligation to perform the main tasks and functions to conduct vocational secondary education. In carrying out its main duties and functions, SMK Negeri 2 Depok Sleman has a vision of the realization of competent human resources schools.

To achieve this vision, SMK Negeri 2 Depok Sleman implemented quality management in its school management which refers to the quality management system ISO 9001: 2008. One of the steps taken by the manager of SMK Negeri 2 Depok Sleman in applying the quality management was the addition of a new organizational structure that specifically manages the human resources of educators and education personnel, namely Vice Principal (VP) of HR. 
In relation to the above, that interestingly researched in the environment of SMK Negeri 2 Depok Sleman was how the model of innovative human resource management of educators and educational staffwere managed specifically by VP Field of human resources and their team ranging from HR quality planning, HR Procurement, Human Resource Development, HR Evaluation and its impact on improving the competence of human resources educators and educational personnel.

Based on the above background exposure, the authors do research with the topic. "Innovative Human Resource Management Model in Vocational High School (Case Study in SMK Negeri 2 Depok Sleman-Yogyakarta).

\section{LITERATURE REVIEW}

\section{A. Human Resource Management}

Human Resource management is more commonly known as HRM or personnel management. According to John M. Ivancevich and Robert Konopaske [2] explains that: "human resource management is the function performed in organizations that facilitates the most effective use of people (employees) to achieve organizational and individual goals". HRM is a function performed within organizations that facilitate the most effective use of people (employees) to achieve organizational and individual goals.

This was in line with the results of research conducted by Stanley T. Asah [3] the researcher citation form International Journalhe concluded that "to human development and capabilities, which are necessary to meet sustainable development goals".

Further more Tb. Sjafri Mangkuprawira [4] state that: HRM Strategic is a system where there is an interrelationship between HRM with the goals and strategic objectives of the company in order to improve company performance and develop a corporate culture that adopts innovation and flexibility.

Based on above concept it can be synthesized that what is meant by HRM is the activity of managing non-material or financial human resources, including planning functions (determination to be performed), organizing (designing and assigning working groups), personnel development (withdrawal, selection, development, compensation and performance appraisal), promotion and termination of employment conducted within organizations that facilitate the most effective use of people (employees) to achieve organizational and individual goals.

\section{B. Quality Planning of Human Resource}

Edward Sallis [5] explained about the quality planning and development of quality plans, he explained that: "The quality plan puts the quality policy statement into action. It show how the processof quality improvement is to be made and maintained. Clearly, it must relate closely to both the corporate and business plans but its focus is different. It outlines the processes to be taken in the medium term to deliver quality improvements. As a result, the quality plan must have clear aims and objectives in relation to quality and the methods through which management commitment is translated into action. Additionally, it must detail the mechanisms through which staff can participate in quality improvement teams. The quality plan should detail the improvement projects that the college intends to carry out".

Further more Syafri Mangkuprawira and Aida Vitalaya Hubeis [6] explains that: The planning of quality of human resources is a form of problem approach, where the decisionmaking process which includes the action to come or which is expected to change the condition of an organization, especially the quality of human resources for the better.

Based on qulathe description above, it can be synthesized that what is meant by the quality planning of human resources is the process of quality improvement related to the institutional plan and business plan, which has objectives related to the quality of human resources, and by using methods to translate management commitments into the implementation of HR management and detailing the HR improvement activities to be implemented by educational institutions in the form of problem approaches, where decision-making processes that include upcoming or expected actions can change the conditions an organization, especially the quality of human resources to be better resulting in a feedback process formulated in the process re-plan the approach of the problem, with the aim of assessing whether the goals and objectives of human resource development have been achieved.

\section{Procurement of Human Resource}

Implementation of HR procurement becomes one of the most important activities in HRM, in that as the beginning of activities to get the right employees fill vacant positions, this was explained by Edwin B. Flippo [7], that: "Procurement this first operative function of personnel necessary to accomplish organization goals. It deals specifically with such subjects as the determination of human resources requirements and their recruitment, selection, and placement. The determination of human resources required must rest upon a prior design of job duties". Based on the description above, it can be synthesized that what is meant by the procurement of human resources is an activity to obtain appropriate types and quantities of personnel needed to accomplish organizational goals that include the determination of human resource needs, the determination of criteria, recruitment, selection, and placement.

\section{Development of Human Resource}

According to Edwin B. Flippo [8], "development has to do with the increase of skill, through training, that is necessary for proper job performance". Development is a skill enhancement through the necessary training for the right job performance, it is a very important activity and will continue 
to grow due to technological changes, job reorganization, increasingly complicated management tasks.

According to Keith Davis [9], some form of human resource development program that is, "training, career planning, performance appraisal". It also deals with the assessment of the success of human resource development programs through education and training undertaken or followed by employees/ members of an organization.

Based on the description above, it can be synthesized that what is meant by the development of human resources is an activity to promote knowledge, skills, competence and improvement of personal and professional behavior, reflecting the individual and organizational focus resulting from commitment to human resources in accordance with the needs of work/ education and training.

\section{E. Evaluation of Human Resource}

Wirawan [10] explains that: Evaluate performance as a process of appraiser (officials) who do the assessment (appraiser)collect information on assessed performance (employee) assessed, formally documented to assess priceless performance by comparing it with performance standards periodically to assist decision making HRM.

Furthermore, according to Dick Grote [11] performance evaluation is "performance appraisal is a formal management system that provides for the evaluation of the quality of an individual's performance in an organization". Performance evaluation is a formal management system provided for the evaluation of the quality of individual performance in an organization.

Based on the above description, it can be synthesized that what is meant by the evaluation of human resources is a systematic assessment to find out the results of work and the performance of members of the organization in accordance with predetermined standards and procedures, determine appropriate job training needs, assign appropriate responsibilities to members of the organization so as to carry out better work in the future and as a basis for supervision activities and to determine policies in terms of promotion or reward.

\section{METHODOLOGY}

The location of research was conducted in SMK Negeri 2 Depok Sleman, Province D.I. Yogyakarta. The study was conducted from February to July 2012.

Implementation of this research activity in grouping into three activities, namely: First, the researchers conducted a grand tour observation in order to obtain data in the early stages, by conducting general interviews, recording the observation and studying documents related to the research object in order to collect data in general. Secondly, the researchers conducted a mini tour observation with the aim to focus and formulate research problems. Third, to observe the participants on the background (setting) the occurrence of human resource management activities of educators and education personnel in SMK Negeri 2 Depok Sleman.

This research was used qualitative approach with case study method. Analysis of data used by concept Robert K.Yin [12], that: "data analysis consists of examining, categorizing, tabulating, testing, or other wise recombining evidence, to draw empirically based conclusions". Analysis of research data includes: test / testing of validity, grouping, merging of data in matrix / table form, then the data are incorrectly combined in accordance with the research questions of each subfocus. After wards the data was combined in the form of tables / matrices then summarized from each answer research questions and grouped according to the source of informants, to describe the results of analysis and research findings. The examination of the validity of the data in this study was conducted into several criteria, namely: credibility (internal validity), transferability (external validity), dependability (reliability), and confirmability (objectivity).

\section{RESULT}

\section{A. Quality Planning of Human Resources}

Based on the review of quality documents at SMK Negeri 2 Depok Sleman, the stages of human resources quality planning in SMK Negeri 2 Depok Sleman can be visualized, as in the following flow:

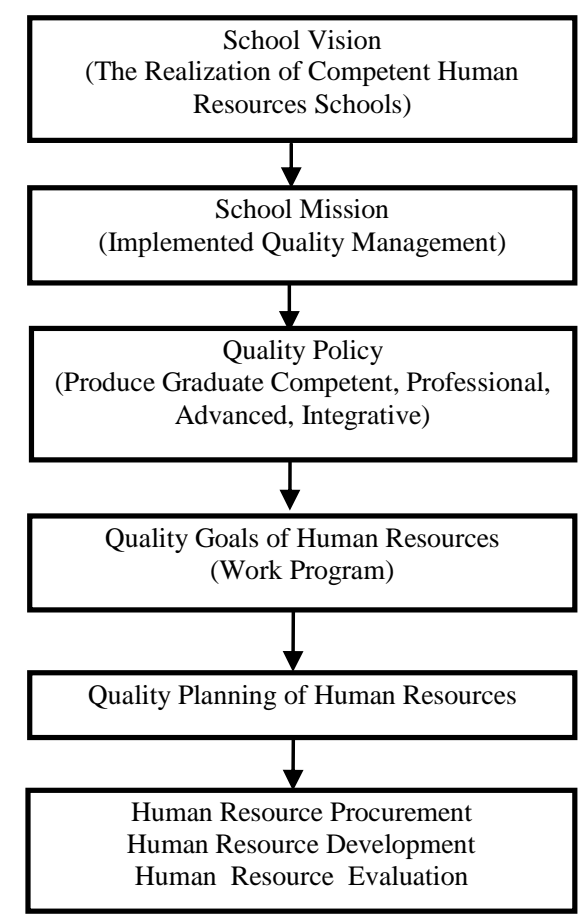

Fig.1. Stages of Quality Planning Human Resources

Furthermore Forms of Human Resource quality planning activities:

- Manager of SMK Negeri 2 Depok Sleman, especially Vice Principal in the field of Human Resources and staff, in 
planning the needs of teachers / educators and staff / education personnel was based on the analysis of the evaluation of teacher needs per subject each semester / year. In it was implementation, Vice Principal HR evaluates for teachers and employees in general, Vice Principal.

- Manager of SMK especially Vice Principal HR, in planning the human resource development program based on the quality plan and quality objectives and quality policy of SMK Negeri 2 Depok Sleman which refers to the vision and mission and policy strategy in the field of manpower. The human resource development plan has been prepared based on the predetermined quality objectives, among which are the number of educators who have completed the minimum education of $20 \%$ and the educators and education personnel who attend training at least $30 \%$ / year.

- Planning of discipline improvement program and the performance of educators and education personnel through the implementation of HR evaluation activities (teacher / employee discipline level min 95\%).

B. The form of activities of the Procurement of Human Resources

- Planning needs of teachers and employees every year is done by analyzing the needs of HR at the beginning of the school year.

- Determination of criteria of prospective teachers and employees to be recruited in accordance with the required competencies based on the results of needs evaluation.

- Proposing the addition of teachers and employees of Civil Servants to the education office, based on the analysis of the needs of human resources per subject and the needs of school management.

- The addition of teachers and non-permanent employees through recruitment activities by the Vice Principal of Human Resources, conducted if teachers and employees of Civil Servants are not fulfilled.

- Proposing the appointment of teachers and employees is not fixed based on the results of recruitment selection.

- Verification of proposals for appointment of NonPermanent Teachers / Non-Permanent Employees by quality management representatives, tailored to available funding budget and school management needs.

- Proposing the establishment of human resources to the principal and the education office.

- Placement of human resources in accordance with the areas of expertise and needs.

\section{Forms of Human Resource Development Activities}

- Human resource development program planning is based on pedagogical, professional, administrative, personality \&social aspects.

- Establishment of implementation team of training activities and human resource development through Decree of Headmaster Determination.

- Implementation of human resource development activities in schools is done through: 1) improvement of formal education S2 and S3; 2) internal and external school training; 3) other development through teacher internship program in company, technical guidance, comparative study, inter-state teacher exchange program; attending outstanding teacher programs and awards.

- Post evaluation of training and development activities is implemented 1-3 months after completion of the training, which aims to determine the impact of training on improving the competence of educators and education personnel on the implementation of tasks.

- Corrective action of training implementation conducted at the end of year to know the level of achievement of development program, and to know constraints and find solution.

- Proposal promotion of additional positions to teachers and employees who are judged to have managerial skills based on evaluation results.

\section{Forms of Human Resource Evaluation Activities}

- Performance monitoring is conducted monthly through attendance, teacher administration check prior to teaching as well as on teaching by principal s / senior teachers on the same subjects.

- Performance appraisal consists of determining the teacher's assessment criteria according to the instrument of teacher administration and attendance, while the criteria of employee appraisal, the standard is performance, discipline and administration of task implementation.

- Performance evaluation is used as an ingredient to plan future development activities conducted at the end of each semester based on the results of monitoring and performance appraisal of administration, discipline and performance.

- Implementation of supervision to educator and educational staff at SMK Negeri 2 Depok Sleman done periodically, that is for educational staff / employees administration is done through internal communication, so found problem problem and solution, while for educator / teacher by way of study in class, and through meetings, and give praise to teachers and employees in the form of teacher / employee appreciation. 
- Program of guidance to teachers and employees of Civil Servants through isedental, disemesteran, special meeting if there is info from the education office and coaching based on the violations that occurred, in the form of oral and written warning 1,2,3 and if not also can be fostered then for educators and civil servants are returned to the education office, while teachers and non-permanent employees will be dismissed.

\section{E. Impact of Specially Managed HRM}

- Indispensable for teacher performance appraisal, all based on performance such as: List of proposed credit score determination, teacher development, teacher profession development, scientific work making, module building and other materials.

- It is very helpful for educators / teachers and educational staff / employees especially in the business of information and facilitate the training and also in conducting the development, in the matter of Determining the Credit Score of Teachers, especially in the submission of personnel affairs, promotion.

- In the process of recruitment of HR carried out according to the criteria and can not Corruption Nepotism Collusion so that Professionalism

- More organized and well organized and well documented in HR management processes and procedures.

- Before any Vice Principal Human Resource handling of human resources handled by the curriculum field so as not to focus, now information from outside related training invitation and human resources development faster.

- Absorption rate of SMK graduates is very high.

\section{CONCLUSION AND RECOMMENDATIONS}

\section{A. Conclusion}

Based on the findings and discussion of the results of research, it can be concluded that SMK Negeri 2 Depok Sleman Yogyakarta has made a new innovation on the management of human resources Educators and Education personnel at school.This was conducted by adding a new organizational structure in the school, namely the establishm of Vice Principal Human Resources whose task is especially to manage the human resources of educators and education personnel. In carrying out it was duties Vice Principal HR assisted by 2 (two) heads section: the head section of educators and educational staff and head of training section. The form of innovative human resource management in SMK Negeri 2 Depok Sleman as follows:

- The quality planning activities of human resources are arranged based on the objectives and the quality policy, consisting of: 1) planning on the needs of educators and education personnel both quantity and quality through the provision of human resources; 2) planning of education improvement programs and the competence of educators and education personnel through human resource development; 3) planning of disciplinary improvement programs and performance of educators and education personnel through HR evaluation.

- Human resource procurement activities are conducted through human resource planning activities, stipulation of proposed / recruited human resources criteria, proposing additional teachers and civil servant education personnel in accordance with the need to the local education office, additional teachers / non-permanent employees through recruitment activities by Vice Principal Human Resources, appointment of teachers and non-permanent employees, verification of proposals for appointment of Non-Permanent Teachers / Non-Permanent Employees, assignment and placement of human resources in accordance with their competencies and school needs.

- Human resource development activities consist of training and development planning, establishment of training and development teams, training and development implementation, post training and development evaluation, training implementation and promotion to well-performing teachers and employees.

- The HR evaluation activities are conducted through monitoring activities, assessment, performance evaluation, supervision and guidance of human resources of educators and education personnel.

\section{- Impact of HRM at SMK Negeri 2 Depok Sleman:}

- Very influential to the improvement of competence and quality of educators and education personnel, this is evidenced by number of teachers and employees who have attended S2 and S3 program. Many teachers are awarded for their achievement, such as provincial achievement teacher, become national jury of student skills competition.

- Provide equal opportunity for teachers and employees to attend training, training, other development either inside / outside school run by Vice Principal Human Resources and Public Relations and Curriculum.

\section{B. Recommendations}

Recommendations are presented to various parties related to the management of SMK human resources in Indonesia and the world, namely:

\section{- Director of Vocational Education}

It was expected that this research can be used as consideration for revision of existing vocational organization structure, in order that the presence of deputy head of human resources that has been applied in SMK Negeri 2 Depok Sleman can be acknowledged and legalized existence, for the management and development of human resources educators and education personnel can be optimally implemented in each SMK, especially in order to implement a competency-based teacher appraisal program in order not to experience difficulties. 


\section{- Manager of SMK}

To SMK managers, it was expected that this research can be used as a reference for all managers of SMK in Indonesia in managing human resources of educators and educational staff, especially in facing the competency-based teacher appraisal program and Implementation of research findings was expected to be applied in other SMK especially for SMK the number of teachers and employees and learners in large numbersand schools that have implemented the quality management system (ISO), in order that not only the competence of students who need to be improved but also the competence of teachers and employees should also be improved, that it was impossible without the support of qualified human resources educators and qualified personnel can produce qualified graduates.

\section{- Educational Management Field Researcher}

This research still needs to be continued, because it has not succeeded in answering the problem of human resource management of educators and educational staff as a whole, especially at the level of private SMK.

\section{REFERENCES}

[1] Berger, Lance A. dan Dorothy R. Berger. Best Practices on Talent Management: Mengidentifikasi, Mengembangkan, dan Mempromosikan Orang Terbaik untuk Membangun Keunggulan Organisasi terjemahan Kumala Insiwi Suryo. Jakarta: Penerbit PPM, 2008, pp. 3-5.

[2] Ivancevich, John M., dan Robert Konopaske."Human Resource Management".New York: McGraw-Hill/Irwin, 2013, p.4.

[3] Asah T Stanley. Post-2015 Development Agenda: Human Agency and the Inoperability of the Sustainable Development Architecture. Journal of Human Development and Capabilities (on line). Volume 16, 2015 issue4,(http://dx.doi.org/10.1080/19452829.2015.1103712).

[4] Mangkuprawira Tb. Sjafri, Manajemen Sumber Daya Manusia Strategik Edisi Kedua. Bogor: Ghalia Indonesia, 2011, p. 1.

[5] Sallis, Edward. "Total Quality Management in Education Third edition".London: Kogan Page, 2002, p.132.

[6] Mangkuprawira, Syafri., dan Aida Vitaliya Hubeis. Manajemen Mutu Sumber Daya Manusia. Bogor: Ghalia Indonesia, 2007, pp.7-8.

[7] [7] Flippo, Edwin B. "Personnel Management Sixth Edition". Arizona: McGraw-Hill, 1984, p.6.

[8] Flippo, Edwin B.’Manajemen Personalia”, TerjemahanM.Mas'ud. Jakarta: Erlangga,1995, p.60.

[9] Davis, keith dan William B. Werther, Jr. "Human Resources and Personnel Management”.New York:McGraw-Hill.Inc., 1996, p. 248.

[10] Wirawan. Evaluasi Kinerja Sumber Daya Manusia. Jakarta: Salemba Empat, 2009, p. 11.

[11] Grote, Dick. "The Performance Appraisal Question and Answer Book". New York: Amacom, 2002, p. 1.

[12] Yin, Robert K. "Case Study Research Design and Methods Fourth Edition”.Thousand Oaks: Sage Publications, 2009, p.99 . 